Anna Pieniak

Uniwersytet w Biatymstoku

\title{
REGULACJE DOTYCZACE USŁUG ODBIERANIA ODPADÓW KOMUNALNYCH ŚWIADCZONYCH PRZEZ PRZEDSIĘBIORCÓW NA GRUNCIE USTAWY O UTRZYMANIU CZYSTOŚCI I PORZĄDKU W GMINACH
}

\section{Wprowadzenie}

Ustawa z dnia 1 lipca 2011 r. o zmianie ustawy o utrzymaniu czystości i porządku $\mathrm{w}$ gminach oraz niektórych innych ustaw (dalej jako u.c.p.g.) ${ }^{1}$ jest kolejną próbą przystosowania krajowych przepisów dotyczących odpadów, w tym odpadów komunalnych do porządku unijnego. Wprowadza ona rewolucyjne zmiany do systemu gospodarowania odpadami komunalnymi. Tworzony system ma umożliwić w szczególności ograniczenie składowania odpadów, w tym ulegających biodegradacji, jak również osiągnięcie do 2020 r. wymaganych przez dyrektywę 2008/98 poziomów przygotowania do ponownego użycia, recyklingu i odzysku innymi metodami wybranych frakcji materiałowych z gospodarstw domowych. ${ }^{2}$

W obecnym systemie gospodarowania odpadami komunalnymi gmina przejęła pełną odpowiedzialność za odpady i system ich zagospodarowania. Zgodnie z obowiązującymi regulacjami do zadań gminy należy zorganizowanie odbioru odpadów komunalnych od właścicieli nieruchomości, na których zamieszkują mieszkańcy i wybór w drodze przetargu podmiotu świadczącego te usługi. Z kolei mieszkańcy ponoszą opłatę na rzecz gminy za świadczone przez nią usługi odbioru i zagospodarowania odpadów komunalnych. Ustawa ta wprowadza także zmiany w zakresie reglamentacji działalności gospodarczej polegającej na odbieraniu odpadów komunalnych od właścicieli nieruchomości. Od dnia 1 stycznia 2012 r. odbieranie odpadów komunalnych stało się działalnością regulowaną, tzn. że dotychczas

Ustawa z dnia 1 lipca 2011 r. o zmianie ustawy o utrzymaniu porządku i czystości w gminach oraz niektórych innych ustaw, Dz.U. z 2011 r. Nr 152, poz. 897, zwana dalej ustawa nowelizująca.

2 M. Duczmal, Najczęściej zadawane pytania. Ustawa o utrzymaniu czystości i porządku w gminach, „Prawo i Środowisko" 2011, nr 3, s. 42 
obowiązujące zezwolenia na odbieranie odpadów komunalnych zostały zastąpione wpisem do rejestru działalności regulowanej prowadzonego przez wójta, burmistrza, prezydenta miasta. Zmiana wymogów formalnych dotyczących prowadzenia tej działalności związana jest z uchyleniem art. 7 ust. 1 pkt 1 ustawy o u.c.p.g., ${ }^{3}$ który stanowił podstawę do wydawania zezwoleń na odbieranie odpadów komunalnych. Celem artykułu jest omówienie zagadnień dotyczących podejmowania i wykonywania przez przedsiębiorców działalności w zakresie odbierania odpadów komunalnych.

\section{Reglamentacja działalności gospodarczej}

Ustawa o swobodzie działalności gospodarczej ${ }^{4} \mathrm{w}$ art. 6 ust. 1 stanowi, że podejmowanie, wykonywanie i zakończenie działalności gospodarczej jest wolne dla każdego na równych prawach. Wyrażona w tym artykule zasada wolności gospodarczej jest zasadą konstytucyjną ujętą w art. 20 Konstytucji RP. ${ }^{5}$ Zawiera ona domniemanie swobody podejmowania i prowadzenia działalności gospodarczej przez poszczególne podmioty, ${ }^{6}$ o ile nie zostanie ona ograniczona w drodze ustawy i ze względu na ważny interes publiczny. Dlatego też przyjmuje się, że wolność gospodarcza nie jest prawem absolutnym, może być ograniczana przez państwo. Owa ingerencja w swobodę wyboru przedmiotu, miejsca, czasu i formy organizacyjnoprawnej prowadzonej działalności gospodarczej stanowi reglamentację działalności gospodarczej.

Reglamentacja działalności gospodarczej nie ma swojej definicji formalnej, dlatego też ustalenie znaczenia tego terminu przysparza sporo trudności, chociażby z uwagi na fakt określenia jej równocześnie mianem funkcji, metody, instrumentu, sposobu, rodzaju czy sfery działalności gospodarczej. ${ }^{7} \mathrm{~W}$ doktrynie można spotkać różne ujęcia reglamentacji, gdyż brakuje jednej powszechnie akceptowanej definicji. Pomijając dyskusje $w$ doktrynie $w$ tym zakresie należy przyjąć, iż reglamentacja jest ingerencją państwa w sferę gospodarki w celu wywołania w niej skutków uznanych przez organy państwa za pożądane z punktu widzenia interesu publicznego, determinowanego niewątpliwie przez cele inne niż ochrona porządku i bezpieczeństwa publicznego. ${ }^{8}$ Przyczyny reglamentacji działalności gospodarczej nie są jednolite, gdyż uzależnione są od warunków i procesów zachodzących w gospodarce. Można je po-

Ustawa z dnia 13 września 1996 r. o utrzymaniu czystości i porządku w gminach, Dz.U. z 2012 r., poz. 391 ze zm., zwana dalej u.c.p.g.

Ustawa z dnia 2 lipca 2004 r. o swobodzie działalności gospodarczej, Dz.U. Nr 173, poz. 1807 ze zm.

Konstytucja Rzeczypospolitej Polskiej z 2 kwietnia 1997 r., Dz.U. Nr 78, poz. 483 ze zm.

S. Biernat, Podejmowanie i prowadzenie działalności gospodarczej - wolność gospodarcza de lege lata i de lege ferenda, „Przegląd Prawa Handlowego” 1994, nr 9, s. 10.

7 J. Boć, Pojęcie administracji, (w:) J. Boć (red.), Prawo administracyjne, Wrocław 2007, s. 357.

8 T. Kocowski, O zezwoleniach policyjnych oraz reglamentacyjnych, (w:) Między tradycją a przeszłością w nauce prawa administracyjnego. Księga jubileuszowa dedykowana Profesorowi Janowi Bociowi, J. Supernat (red.), Wrocław 2009, s. 350. 
Regulacje dotyczące usług odbierania odpadów komunalnych świadczonych...

dzielić na przyczyny o charakterze obiektywnym i subiektywnym. Pierwsza grupa ograniczeń wynika z zagrożeń, jakie związane są z wykonywaniem niektórych rodzajów działalności gospodarczej, jak np. zagrożeń dla życia lub zdrowia ludzkiego i moralności publicznej czy obronności i bezpieczeństwa państwa lub obywateli. ${ }^{9}$ Drugą grupę tworzą przyczyny wnikające z aktualnej polityki gospodarczej państwa, zobowiązań z członkostwa w międzynarodowych organizacjach gospodarczych. ${ }^{10}$ Przesłanki o charakterze subiektywnym, zdaniem R. Biskupa, powinny być stosowane tylko wyjątkowo, kiedy inne środki zmierzające do realizacji założonych przez nie celów zawiodą lub kiedy wymagają tego zobowiązania międzynarodowe dobrowolnie przyjęte. ${ }^{11}$

Reglamentacja działalności gospodarczej ma na celu wyznaczenie granic swobody podejmowania i wykonywania działalności gospodarczej. Ponadto określa zakres ingerencji państwa w tę swobodę. Ingerencja ta powinna być wyznaczona zgodnie z zasadą proporcjonalności, według której ograniczenie wolności gospodarczej powinno być jak najmniejsze i najmniej uciążliwe, a zarazem wystarczające dla realizacji określonego celu, a nadto wykorzystanie tego środka reglamentacji powinno być konieczne. ${ }^{12}$

Przedmiotem reglamentacji działalności gospodarczej są między innymi usługi użyteczności publicznej. Pojęcie użyteczność publiczna zostało określone w art. 1 ust. 2 ustawy o gospodarce komunalnej, ${ }^{13}$ zgodnie z którym gospodarka komunalna obejmuje w szczególności zadania o charakterze użyteczności publicznej, których celem jest bieżące i nieprzerwane zaspokajanie zbiorowych potrzeb ludności w drodze usług powszechnie dostępnych. Co do zasady wykonywanie tych zadań należy do kompetencji jednostek samorządu terytorialnego, a w szczególności zadań własnych gminy. Gmina za realizację tych zadań ponosi odpowiedzialność, dlatego też może decydować, czy będzie je wykonywać we własnym zakresie przez gminne jednostki organizacyjne, czy też powierzy ich realizację podmiotom prywatnym. Przekazanie przez gminę usług o charakterze użyteczności publicznej następuję w drodze udzielenia przez organ gminy stosownego zezwolenia na rzecz przedsiębiorcy (np. zezwolenie na zbiorowe zaopatrzenie w wodę i zbiorowe odprowadzanie ścieków). ${ }^{14}$ Wójt jest więc organem reglamentacyjnym w sferze usług o charakterze użyteczności publicznej. Kompetencje reglamentacyjne gminy polegają na wydawaniu bądź odmowie wydania zezwolenia na prowadzenie działalności gospodarczej w określonych dziedzinach na terenie danej gminy. Ponadto gmina może kształtować warunki

9 T. Kocowski, Publiczne prawo gospodarcze Polski i Unii Europejskiej, Warszawa 2007, s. 187-188.

10 R. Biskup, Wolność gospodarcza w wymiarze podmiotowym, Lublin 2011, s. 61.

11 Ibidem.

12 A. Powałowski, Zakres swobody podejmowania działalności gospodarczej, „Gdańskie Studia Prawnicze” 2005, t. XIV, s. 572-573.

13 Ustawa z dnia 20 grudnia 1996 r. o gospodarce komunalnej, Dz.U. z 2011 r. Nr 45, poz. 236.

14 M. Szydło, Koncepcja koncesji w ujęciu klasycznym i jej recepcja w prawie polskim, „Państwo i Prawo” 2004, nr 1, s. 53. 
wykonywania tej działalności uchwalając akty o charakterze generalnym. Istotne jest przy tym to, że rozwiązania owych aktów znajdują wyraz w treści aktów indywidualnych - w zezwoleniach. Kształtowanie warunków wykonywania działalności gospodarczej w danej sferze użyteczności publicznej może być postrzegane jako swoiste rozszerzenie zakresu reglamentacji wolności gospodarczej, ale także jako element organizowania usług na rynku lokalnym. ${ }^{15}$

Ustawa o utrzymaniu czystości i porządku w gminach poddaje reglamentacji usługi związane $\mathrm{z}$ utrzymanie czystości i porządku, do których należy między innymi odbieranie odpadów komunalnych od właścicieli nieruchomości. Przedmiotem reglamentacji jest więc działalność polegająca na odbieraniu odpadów komunalnych, przy czym przez odpady komunalne należy rozumieć odpady w rozumieniu ustawy z dnia 14 grudnia 2012 r. o odpadach. ${ }^{16}$ Zgodnie $z$ art. 3 ust. 1 pkt 7 tej ustawy przez odpady komunalne rozumie się odpady powstające w gospodarstwach domowych, z wyłączeniem pojazdów wycofanych z eksploatacji, a także odpady niezawierające odpadów niebezpiecznych pochodzące od innych wytwórców odpadów, które ze względu na swój charakter lub skład są podobne do odpadów powstających w gospodarstwach domowych. Ponadto definicja ta wskazuje, że zmieszane odpady komunalne pozostają nadal zmieszanymi odpadami komunalnymi, nawet jeśli zostały one poddane czynności przetwarzania odpadów, która nie zmieniła w sposób znaczący ich właściwości.

Zarówno przed nowelizacją ustawy o u.c.p.g., jak i w obowiązującym stanie prawnym przedsiębiorca, których chciał podjąć działalność w zakresie odbierania odpadów komunalnych musiał spełnić warunki przewidziane przepisami ustawy. Przede wszystkim musiał uzyskać zezwolenie na odbieranie odpadów komunalnych, a obecnie wpis do rejestru działalności regulowanej.

\section{Wpis do rejestru działalności regulowanej}

Ustawa nowelizująca, jak już podkreślano, wprowadziła zmiany w zakresie reglamentacji działalności gospodarczej polegającej na odbieraniu odpadów komunalnych. W świetle art. $9 \mathrm{~b}$ ust. 1 u.c.p.g. działalnością w zakresie odbierania odpadów komunalnych jest działalność regulowana w rozumieniu ustawy o swobodzie działalności gospodarczej. Działalność regulowana jest najmniej uciążliwą formą ograniczania swobody działalności gospodarczej. Do jej podjęcia niezbędne jest spełnienie szczególnych warunków przewidzianych w ustawie o u.c.p.g. oraz uzyskanie wpisu do rejestru działalności regulowanej. Działalność ta nie wymaga więc uzyskania in-

\footnotetext{
15 B. Popowska, Reglamentacja i określenie przez gminy warunków wykonywania usług użyteczności publicznej. Wpływ na konkurencję i kontrola sądów, (w:) H. Nowicki, W. Szwajdler (red.), Konstytucyjna zasada wolności gospodarczej, Toruń 2009 , s. 347. 
Regulacje dotyczące usług odbierania odpadów komunalnych świadczonych...

dywidualnego aktu administracyjnego - zezwolenia na wykonywanie działalności w omawianym zakresie.

W obecnie obowiązującym stanie prawnym podstawą podjęcia działalności w zakresie odbierania odpadów jest uzyskanie przez przedsiębiorcę wpisu do rejestru działalności regulowanej prowadzonego przez wójta, burmistrza, prezydenta miasta. Obowiązek uzyskania wpisu powstaje z chwilą, gdy podmiot podjął decyzję o zamiarze wykonywania działalność w zakresie odbierania odpadów. Spełnienie tego warunku musi nastąpić przed fizycznym rozpoczęciem jej wykonywania, w przeciwnym razie taką działalność należy uznać za nielegalną, niezgodną z przepisami prawa.

Zgodnie z treścią art. 65 u.s.d.g. przedsiębiorca, który zamierza podjąć działalność gospodarczą musi złożyć pisemny wniosek oraz oświadczenie o spełnianiu warunków wymaganych do wykonywania działalności regulowanej. Ustawa o utrzymaniu czystości i porządku w gminach w art. 9c ust. 4 u.c.p.g. również wskazuje, iż podstawą działalności w zakresie odbierania odpadów komunalnych jest spełnienie wymogów materialnych i formalnych, a co niewątpliwie wiąże się z obowiązkiem złożenia stosownego oświadczenia oraz wniosku o wpis do rejestru. Treść oświadczenia o spełnieniu warunków wymaganych do wykonywania działalności w zakresie odbierania odpadów komunalnych powinna zawierać w szczególności potwierdzenie, że podmiot ubiegający się o wpis zna i spełnia warunki przewidziane przepisami u.c.p.g. Oświadczenie to powinno być zgodne ze stanem faktycznym, przy czym należy zauważyć, że zarówno ustawa o utrzymaniu czystości i porządku w gminach, jak i ustawa o swobodzie działalności gospodarczej nie przewidują sankcji karnych za niezgodne z prawdą oświadczenie. Weryfikacja prawidłowości złożonego oświadczenia następuje dopiero ex post, a więc już w trakcie wykonywania działalności przez przedsiębiorcę. Konsekwencją kontroli ex post jest to, iż organ rejestrowy w momencie dokonywania wpisu do rejestru jest obowiązany jedynie do sprawdzenia, czy oświadczenie złożone przez wnioskodawcę spełnia warunki formalne przewidziane w przepisach ustawy o u.c.p.g. Wpis do rejestru działalności regulowanej jest zatem czynnością materialno-techniczną o charakterze deklaratoryjnym, ponieważ po stronie przedsiębiorcy nie powstaje żadne uprawnienie w związku z uzyskaniem wpisu. ${ }^{17}$

Wykonywanie działalności w zakresie odbierania odpadów, jak już zostało powiedziane, jest uzależnione od spełnienie szczególnych wymagań określonych w ustawie o u.c.p.g. Jednakże w tym miejscu należy się zastanowić, czy dla zadośćuczynienia warunkom wykonywania tej działalności wystarczy spełnienie wymagań określonych w art. 9d u.c.p.g. i rozporządzeniu wykonawczym do tego przepisu wydanym przez Ministra Ochrony Środowiska. ${ }^{18}$ Zdaniem M. Górskiego spełnienie

17 Wyrok WSA w Gliwicach z dnia 7 listopada 2012 r., sygn. akt III SAB/ GI 19/12.

18 Rozporządzenie Ministra Ochrony Środowiska z dnia 11 stycznia 2013 r. w sprawie szczególnych wymagań w zakresie odbierania odpadów od właścicieli nieruchomości, Dz.U. z 2013 r., poz. 122. 
warunków wykonywania działalności wiąże się nie tylko z obligatoryjnym wypełnieniem wymagań przewidzianych art. 9d i rozporządzeniu, ale także ze spełnieniem obowiązków dotyczących sposobu prowadzenia działalności określonych w art. 9 e-h tej ustawy. Autor ten stwierdzenie to opiera na wykładni językowej odpowiednich przepisów ustawy i wynikającym z niej założeniu, że warunki, o których mowa w art. 9c ust. 4 u.c.p.g., to coś szerszego niż wymagania, do których odnosi się art. $9 d$ u.c.p.g. Jego zdaniem, ustawodawca w art. 9d celowo użył słowa wymagania zamiast warunki, aby podkreślić, iż ich spełnienie nie jest wystarczające do właściwego zgodnego z prawem wykonywania tej działalności. Dlatego aby oświadczenie o spełnieniu warunków wykonywania działalności było zgodne z ustawą, przedsiębiorca zobowiązuje się w nim do spełnienia konkretnych wymagań w momencie przystąpienia do wykonywania działalności, jak i do przestrzegania wymaganych obowiązków w trackie prowadzenia działalności. ${ }^{19}$

Przepisy ustawy o utrzymaniu czystości i porządku w gminach nakładają na przedsiębiorców cały szereg nowych obowiązków, które muszą wypełniać, aby wykonywać działalność zgodnie z jej postanowieniami. Ich katalog został rozszerzony w stosunku do poprzednio obowiązujących przepisów i przewiduje następujące obowiązki dla podmiotów odbierających odpady komunalne od właścicieli nieruchomości:

1. Przekazywanie odebranych od właścicieli nieruchomości selektywnie zebranych odpadów komunalnych do instalacji odzysku i unieszkodliwiania odpadów, zgodnie z hierarchią postępowania z odpadami określoną w ustawie o odpadach (w przypadku niedopełnienia przez właściciela nieruchomości obowiązku w zakresie selektywnego zbierania odpadów komunalnych przedsiębiorca przyjmuje je jako zmieszane odpady komunalne i powiadamia o tym gminę);

2. Przestrzeganie zakazu mieszania selektywnie zabranych odpadów komunalnych ze zmieszanymi odpadami komunalnymi odbieranymi od właścicieli nieruchomości. Przedsiębiorca, który miesza selektywnie zebrane odpady komunalne podlega karze pieniężnej zgodnie $\mathrm{z}$ art. 9x ust. 1 pkt 2 u.c.p.g.;

3. Osiągnięcie w danym roku kalendarzowym poziomów odzysku i recyklingu oraz zmniejszania masy odpadów komunalnych ulegających biodegradacji deponowanych na składowiskach odpadów. W przypadku przyjęcia przez gminę obowiązków właściciela nieruchomości za osiągnięcie odpowiednich poziomów odzysku i recyklingu oraz redukcji masy odpadów ulegających biodegradacji w stosunku do strumienia odpadów komunalnych odebranych od właściciela nieruchomości z terenu gminy odpowiada bezpośrednio gmina. Jako faktyczny dysponent odpadów odebranych od właściciela nieruchomości ponosi wyłączną odpowiedzialność za odpady komunalne 
Regulacje dotyczące usług odbierania odpadów komunalnych świadczonych...

odebrane przez zorganizowany przez siebie system dobierania odpadów komunalnych;

4. Przekazanie zmieszanych odpadów komunalnych, odpadów zielonych oraz pozostałości z sortowania odpadów komunalnych przeznaczonych do składowania, odebranych od właściciela nieruchomości, do regionalnej instalacji do przetwarzania odpadów komunalnych, wskazanej w uchwale w sprawie realizacji wojewódzkiego planu.

Wykreślenie przedsiębiorcy z rejestru działalności regulowanej, jak słusznie zauważa M. Górski, ${ }^{20}$ ma dwie różne podstawy prawne i wynikające $\mathrm{z}$ nich dwie odrębne formy prawne. W związku z czym wykreślenie z rejestru może mieć charakter porządkowy lub sankcji administracyjnej. Według tego autora wykreślenie o charakterze porządkowym odnosi się do sytuacji, w której przedsiębiorca zamierza zakończyć wykonywanie działalności objętej wpisem i powiadamia o tym właściwy organ rejestrowy. Wówczas takie wykreślenie następuje na wniosek zainteresowanego podmiotu. Zgodnie z treścią art. 9i u.c.p.g. ustawodawca wyznaczył przedsiębiorcy termin 14-dniowy na złożenie wniosku o wykreślenie z rejestru liczony od dnia trwałego zaprzestania wykonywania tej działalności. A więc trwałe zaprzestanie wykonywania działalności należy uznać za podstawę złożenia przedmiotowego wniosku. Termin trwałe, zdaniem M. Górskiego, należy interpretować jako faktyczne wycofanie się przedsiębiorcy z działalności na terenie danej gminy. Autor ten zauważa, że trwałe zaprzestanie wykonywania działalności nie można wiązać z sytuacją, w której przedsiębiorca stracił możliwość prowadzenia tej działalności z prawnego punktu widzenia, np. przetarg na odbieranie lub odbieranie i zagospodarowanie odpadów komunalnych rozstrzygnięto na jego niekorzyść. Rozróżnienie tych dwóch sytuacji ma wpływ na konsekwencje prawne niezłożenia wniosku o wykreślenie $\mathrm{z}$ rejestru $\mathrm{w}$ terminie, a ich zastosowanie będzie wynikać z przeprowadzonej oceny, czy zaprzestanie wykonywania działalności ma cechy trwałości. ${ }^{21}$ W razie stwierdzenia przez organ rejestrowy trwałego zaprzestania wykonywania działalności przedsiębiorca, bez żadnej sankcji prawnej, zostanie wykreślony z rejestru na podstawie art. 9 j ust. 2 pkt 2 u.c.p.g. ${ }^{22}$ Ponadto należy podkreślić, iż ta forma wykreślenia z rejestru ma charakter czynności materialno-technicznej dokonywanej przez organ rejestrowy na wniosek zainteresowanego podmiotu.

Zdaniem M. Górskiego, ${ }^{23}$ wykreślenie z rejestru o charakterze sankcji administracyjnej ma miejsce wtedy, gdy przedsiębiorca nie wykonuje w należyty sposób obowiązków nałożonych na niego przepisami prawa. Oceny tej dokonuje wójt, bur-

\footnotetext{
20 M. Górski, Wykreślenie przedsiębiorcy z rejestru działalności regulowanej, „Przegląd Komunalny” 2012, nr 4, s. 24 Ibidem. W. Radecki, Ustawa o utrzymaniu czystości i porządku w gminach. Komentarz, Warszawa 2012, s. 227. M. Górski, Wykreślenie przedsiębiorcy z rejestru..., op. cit.
} 
mistrz, prezydent miasta biorąc pod uwagę zarówno przepisy ustawy o swobodzie działalności gospodarczej, jak i ustawy o utrzymaniu czystości i porządku w gminach. Wykreślenie z rejestru następuje więc w przypadkach, o których mowa $\mathrm{w}$ art. 71 ust. 1 u.s.d.g. oraz art. $9 j$ ust. 2 u.c.p.g., $g d y^{24}$ :

1) wydano prawomocne orzeczenie zakazujące przedsiębiorcy wykonywania działalności gospodarczej objętej wpisem;

2) stwierdzono, że przedsiębiorca nie spełnia wymagań określonych dla podmiotu odbierającego odpady komunalne od właścicieli nieruchomości;

3) stwierdzono, że przedsiębiorca po raz drugi przekazuje zmieszane odpady komunalne, odpady zielone lub pozostałości z sortowania odpadów komunalnych przeznaczonych do składowania do instalacji innych niż regionalne instalacje do przetwarzania odpadów komunalnych;

4) przedsiębiorca, który nie działa na podstawie umowy lub nie świadczy usługi odbierania odpadów komunalnych w trybie zamówienia z wolnej ręki, w kolejnym roku kalendarzowym nie osiągnął poziomów recyklingu, przygotowania do ponownego użycia i odzysku innymi metodami oraz ograniczenia masy odpadów komunalnych ulegających biodegradacji przekazywanych do składowania.

Sankcja administracyjna w tym przypadku polega na zakazie wykonywania działalność polegającej na odbieraniu odpadów komunalnych, przy czym porównując przepisy tych dwóch ustaw można mówić o różnym charakterze represyjnym tych sankcji. Stwierdzenie naruszeń przepisów prawa na podstawie art. 71 ust. 1 u.s.d.g. skutkuje tym, że organ rejestrowy, tzn. wójt, burmistrz, prezydent miasta obligatoryjnie wydaje decyzję o zakazie wykonywania przez przedsiębiorcę działalności, która na mocy ust. 2 podlega natychmiastowemu wykonaniu. Zdaniem W. Radeckiego, mamy tu do czynienia z sytuacją określoną w art. $130 \S 3$ pkt 2 k.p.a. - bez konieczności nadania decyzji rygoru natychmiastowej wykonalności decyzja podlega natychmiastowemu wykonaniu. Od decyzji przysługuje wprawdzie odwołanie do samorządowego kolegium odwoławczego, a następnie skarga do sądu administracyjnego, ale wniesienie odwołania nie wstrzymuje wykonania decyzji. ${ }^{25}$ Wydanie decyzji o zakazie wykonywania działalność jest jednoznaczne z wykreśleniem przedsiębiorcy z rejestru z urzędu, jak również skutkuje koniecznością wykreślenia ze wszystkich rejestrów gminnych, w których dany przedsiębiorca uzyskał wpis. ${ }^{26}$ Ponadto należy zauważyć, że przedsiębiorca będzie mógł ubiegać się o ponowne wpisanie do rejestru dopiero po upływnie trzech lat od dnia wydania decyzji o zakazie wykonywania działalności. 
Regulacje dotyczące usług odbierania odpadów komunalnych świadczonych...

$\mathrm{Z}$ kolei wykreślenie z rejestru na postawie art. 9j ust. 2 u.c.p.g. nie jest uzależnione od uprzedniego wydania przez organ rejestrowy decyzji o zakazie wykonywania działalności objętej wpisem. Dlatego też, zdaniem W. Radeckiego i M. Górskiego, art. 9j ust. 2 tej ustawy należy traktować autonomicznie. Wykreślenie z rejestru nie jest decyzją administracyjną, a jedynie czynnością faktyczną wójta, burmistrza, prezydenta miasta, której można przypisać status czynności materialno-technicznej. W związku z powyższym nie przysługuje od niej odwołanie, jak ma to miejsce w przypadku decyzji o zakazie wykonywania działalności, co niewątpliwie osłabia pozycję prawną przedsiębiorcy. Można jednak argumentować, że wykreślenie z rejestru jest czynnością z zakresu administracji publicznej, dlatego też kontrola takiego rozstrzygnięcia powinna być realizowana w trybie art. $3 \S 1$ pkt 4 ustawy z dnia 30 sierpnia 2002 r. Prawo o postępowaniu przed sądami administra-

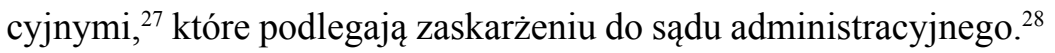

\section{Podsumowanie}

Zgodnie z uzasadnieniem do ustawy nowelizującej wprowadzenie rejestru działalności regulowanej ma się przyczynić do zwiększenia wolności gospodarczej w Polsce w zakresie odbierania odpadów komunalnych od właścicieli nieruchomości, ponieważ uzyskanie wpisu do rejestru działalności regulowanej jest łatwiejsze, niż uzyskanie zezwolenia na odbieranie odpadów komunalnych. Organ rejestrowy nie będzie sprawdzał zgłoszonych danych, informacji i dokumentów przed dokonaniem wpisu do rejestru, a może je sprawdzić dopiero ex post. Zatem sama deklaracja o spełnieniu warunków do prowadzenia działalności w zakresie odbierania odpadów komunalnych będzie wystarczająca do rozpoczęcia tej działalności. ${ }^{29} \mathrm{Kwestia}$ ta jest mocno dyskusyjna, gdyż z jednej strony wpis do rejestru działalności regulowanej jest niewątpliwej pewnym ułatwieniem dla przedsiębiorców, ale z drugiej strony jego uzyskanie nie uprawnia do jej wykonywania, gdyż przedsiębiorca przed jej rozpoczęciem musi wygrać przetarg na odbieranie odpadów komunalnych i zawrzeć z gminą umowę na świadczenie usług. Jednakże należy zauważyć, że sytuacja ta odnosi się do przedsiębiorców, którzy zamierzają prowadzić działalność w zakresie odbierania odpadów komunalnych od właścicieli nieruchomości, na których zamieszkują mieszkańcy. Gmina staje się zatem jedynym nabywcą usługi na danym lokalnym rynku odbioru odpadów komunalnych. We wprowadzonym modelu odbiór odpadów komunalnych jest finansowany przez gminę z podatku od śmieci po-

27 Ustawa z dnia 30 sierpnia 2002 r. - Prawo o postępowaniu przed sądami administracyjnymi, Dz.U. Nr 153, poz. 1270 ze zm.

28 W. Radecki, Ustawa o utrzymaniu, op. cit., s. 230-231; M. Górski, Wykreślenie przedsiębiorcy z rejestru, op. cit.

29 Uzasadnienie do projektu ustawy o zmianie ustawy o utrzymaniu czystości i porządku w gminach oraz niektórych inny ustaw, druk sejmowy nr 3670, s. 16. 
bieranego od wytwórców odpadów. ${ }^{30}$ Ponadto wprowadzenie trybu przetargowego ograniczy konkurencję na rynku odbierania odpadów komunalnych. Przetarg może wygrać tylko jeden podmiot spełniający warunki określone w SIWZ. Będzie on świadczyć usługi na terenie całej gminy, o ile nie zostanie ona podzielona na sektory. Taka sytuacja może doprowadzić do wyeliminowania przedsiębiorców prowadzących działalność konkurencyjną na danym rynku, co spowoduje brak rzeczywistej konkurencji w przypadku kolejnych przetargów, do których może brakować zainteresowanych. ${ }^{31}$

30 P. Brzeziński, Problematyka udzielania przez gminy zamówień publicznych podmiotom zewnętrznym na odbiór odpadów komunalnych, „Państwo i Prawo” 2014, nr 4, s. 37.

31 D. Wałkowski, 10 problemów prawnych związanych z nowym systemem gospodarowania odpadami komunalnymi, „Prawo i Środowisko” 2011, nr 4, s. 79. 
Regulacje dotyczące usług odbierania odpadów komunalnych świadczonych...

\section{LEGAL REGULATIONS WITH REGARDS TO THE SERVICE OF MUNICIPAL WASTE COLLECTION PROVIDED BY ENTREPRENEURS UNDER THE ACT ON MAINTAINING CLEANLINESS AND ORDER IN MUNICIPALITIES}

The amended act of 1 July 2011 introducing changes to the act on maintaining cleanliness and order in municipalities and to some other acts, amounted to significant alterations in the waste management system. One of them concerns amendment to the regulation of economic activity in regards to the collection of municipal waste. Thus the permission for the aforementioned services has been replaced by the obligation to obtain entry to the Record Book of Economic Activities. This solution undoubtedly benefits entrepreneurs since the procedures which led to the administrative decision are no longer required. The aim of the article is therefore to discuss the conditions of undertaking and performing the activities by entrepreneurs in regards to the collection of municipal waste on the basis of entry to the Record Book of Economic Activities.

Keywords: municipal waste, regulated activity, entrepreneur 